\title{
Nutrient Components and in vitro Digestibility of Treated and Untreated Date Palm Wastes with Mushroom (Pleurotus florida)
}

\author{
Ahmed El-Waziry ${ }^{1 *}$, Fahad Alkoaik ${ }^{2}$, Ahmed Khalil ${ }^{2,3}$, Hassan Metwally $^{1}$, Ronnel Fulleros ${ }^{2}$ \\ ${ }^{1}$ Department of Animal Production, College of Food and Agriculture Sciences, King Saud University, Kingdom \\ of Saudi Arabia; ${ }^{2}$ Department of Agricultural Engineering, College of Food and Agriculture Sciences, King Saud \\ University, Kingdom of Saudi Arabia; ${ }^{3}$ Department of Environmental Studies, Institute of Graduate Studies and \\ Research, University of Alexandria, Alexandria, Egypt.
}

\begin{abstract}
The current study aimed to evaluate date palm wastes (DPW) and treaded date palm wastes (TDPW) called "spent mushroom substrate" as alternative feeds for ruminants using chemical composition and in vitro gas production technique. Rumen liquor was obtained from three canulated goats fed on concentrate mixture and alfalfa hay. The gas production was recorded after $3,6,9,12,24,48$ and $72 \mathrm{~h}$ of incubation. The values of crude protein (CP), ether extract (EE), crude fiber (CF) and nitrogen free extract (NFE) in TDPW were higher than that in DPW. The extent of gas production at $72 \mathrm{~h}$ was 23.44 and $23.00 \mathrm{ml}$ for DPW and TDPW, respectively. The values of potential degradability $(\mathrm{a}+\mathrm{b})$ were 23.39 and $22.94 \mathrm{ml}$ and 0.092 and 0.094 for the rate of gas production (c) in DPW and TDPW, respectively. There were significant $(\mathrm{p}<0.05)$ differences between DPW and TDPW in Metabolizalbe energy $(\mathrm{ME})$, net energy (NE), organic matter digestibility (OMD) and microbial protein (MP). There was no significant $(\mathrm{p}>0.05)$ difference between DPW and TDPW in short chain fatty acids (SCFA). It could be concluded that treatment of date palm wastes with mushroom improved the potential feeding value of the resultant substrate, and a good potential as feed resources for ruminants.
\end{abstract}

Keywords | Date palm wastes, Spent mushroom substrate, Gas production, Energy, Microbial protein

Editor | Kuldeep Dhama, Indian Veterinary Research Institute, Uttar Pradesh, India.

Received | February 19, 2016; Accepted | April 09, 2016; Published | April 28, 2016

*Correspondence | Ahmed El-Waziry, Department of Animal Production, College of Food and Agriculture Sciences, King Saud University, Kingdom of Saudi Arabia; Email: aelwaziry@yahoo.com

Citation | El-Waziry A, Alkoaik F, Khalil A, Metwally H, Fulleros R (2016). Nutrient components and in vitro digestibility of treated and untreated date palm wastes with mushroom (Pleurotus florida). Adv. Anim. Vet. Sci. 4(4): 195-199.

DOI | Http://dx.doi.org/10.14737/journal.aavs/2016/4.4.195.199

ISSN (Online) | 2307-8316; ISSN (Print) | 2309-3331

Copyright (C) 2016 El-Waziry et al. This is an open access article distributed under the Creative Commons Attribution License, which permits unrestricted use, distribution, and reproduction in any medium, provided the original work is properly cited.

\section{INTRODUCTION}

$\mathrm{T}$ he increase in feed price and shortage in green fodder promoted nutritionists to search for cheaper alternative feeds. Kingdom of Saudi Arabia is arid areas described by low rainfall and underground water, so it have a low primary production and forage quality. Under these environments, it is useful to use desert plants, shrubs or/and tree leaves. The date palm (Phoenix dactylifera L.) trees are drought tolerant and salinity and it described as the natural resources. It is possible to use date palm residues after harvest dates from the trees as a type of roughage feed in ruminant diets. The number of date palms, as well as date production and consumption, vary among produced countries due to prevailing environmental conditions, the pro- duction purpose of this crop and social conventions of each country (El-Waziry et al., 2013). Some studies showed the date palm leaves can used in ruminant nutrition as alternative feeds (E1-Waziry et al., 2013; Pascual et al., 2000; Bahman et al., 1997). A date palm tree usually produces about $20 \mathrm{~kg}$ of leaves (E1-Waziry et al., 2013). However, with regards to their possible using, the information about feed intake and nutritive value of date palm leaves in ruminants are limited (Pascual et al., 2000). Bahman et al. (1997) noted that date palm leaves might be suitable alternative roughages in highly concentrated diets. Thus, agriculture by-products can be used as alternative feeds for animals such as date palm leaves after harvested the dates in its dry form or in the form of silage (El-Waziry et al., 2013). Recently, Khalil et al. (2015) reported the cultivation of 
oyster mushroom (Pleurotus florida) on date palm wastes, and the end of several mushroom harvests, the growing material is considered spent oyster mushroom substrate contains enough digestible nutrients and may be suitable to feed animals. Therefore, the current study aimed to evaluate date palm wastes and treaded date palm wastes (spent mushroom substrate) as alternative feeds for ruminants using chemical composition and in vitro gas production technique.

\section{MATERIALS AND METHODS}

Dried date palm wastes (branches and leaves) were collected from the Educational Farm, Department of Agricultural Engineering, College of Food and Agriculture Sciences, University of King Saud, Riyadh City, Saudi Arabia, and chopped into $2-3 \mathrm{~cm}$. A treaded date palm waste (spent mushroom substrate) was prepared according to Khalil et al. (2015).

In vitro gas production was undertaken according to Menke and Steingass (1988). Rumen liquor was obtained from three cannulated goats fed on concentrate mixture and alfalfa hay. Buffer solution was prepared according to Onodera and Handerson (1980) and placed in a shaker water bath at $39^{\circ} \mathrm{C}$ with continuous flushing of $\mathrm{CO}_{2}$. Approximately $200 \mathrm{mg}$ air dry of date palm wastes (DPW) and treaded date palm waste samples (TDPW) were placed into each syringe. Twenty four syringes were divided to two groups; each group consists of six replicates, two syringes each. The rumen fluid was mixed with buffer at $1: 2 \mathrm{v} / \mathrm{v}$, and $30 \mathrm{ml}$ were placed into each syringe, containing the samples (200 mg) according to Blümmel and Ørskov (1993). Four syringes with only buffered rumen fluid were incubated as the blank. The incubation procedure was repeated three times. The gas production was recorded after 3, 6, 9, 12, 24, 48 and $72 \mathrm{~h}$ of incubation. The values of total gas production were corrected for the blank sample. Cumulative gas production values was fitted to the potential equation, Gas $(Y)=a+b\left(1-\exp ^{-c t}\right)$, where; $a=$ the gas production from the immediately soluble fraction, $b=$ the gas production from the insoluble fraction, $a+b=$ potential degradability, $c$ the gas production rate constant for the insoluble fraction (b), t = incubation time, according to the model of Ørskov and McDonald (1979).

The energy values of DPW and TDPW were calculated from the amount of gas produced at $24 \mathrm{~h}$ of incubation with supplementary analysis of crude protein, ash, crude fat (Menke et al., 1979; Menke and Steingass, 1988).

$$
\begin{gathered}
M E(M J / k g D M)=2.2+0.136 G P+0.057 C P+0.0029 C F \\
O M D(\%)=14.88+0.889 G P+0.45 C P+0.0651 X A
\end{gathered}
$$

where: $\mathrm{ME}$ is the metabolizable energy; OMD is organic matter digestibility; GP is $24 \mathrm{~h}$ net gas production $(\mathrm{ml} / 200$ $\mathrm{mg} \mathrm{DM}) ; \mathrm{CP}$ is crude protein (\% DM); $\mathrm{CF}$ is crude fat (\% $\mathrm{DM})$; $\mathrm{XA}$ is ash (\% DM), as given below:

$$
\begin{gathered}
N E(M c a l / l b)=\left(2.2+\left(0.0272^{*} \text { Gas }\right)+\right. \\
\left.\left(0.057^{*} C P\right)+\left(0.149^{*} E E\right)\right) / 14.64
\end{gathered}
$$

where:

Gas is $24 \mathrm{~h}$ net gas production $(\mathrm{ml} / \mathrm{g} \mathrm{DM})$; $\mathrm{CP}$ is crude protein (\% DM); $\mathrm{EE}$ is Ether extract (\% DM), Then net energy unit converted to be $\mathrm{MJ} / \mathrm{kg} \mathrm{DM}$.

Microbial protein (MP) was calculated according to Czerkawski (1986) as:

$$
M P(g / \mathrm{kg} O M D)=O M D X 19.3 \times 6.25
$$

where:

OMD is organic matter digestibility for $24 \mathrm{~h}$.

The gas production caused by fermentation of the soluble fraction (GPSF) and insoluble fraction (GPNSF) was calculated by gas produced after $3 \mathrm{~h}$ and $24 \mathrm{~h}$ of the incubation, respectively, according to Van Gelder et al. (2005). Short chain fatty acids concentration was calculated as described by Menke et al. (1979).

GPSF $(\mathrm{ml})=\left(\right.$ gas at $\left.3 h r^{*} 0.99^{*} 5\right)-3$
GPNSF $(\mathrm{ml})=(1.02 *(($ gas at $24 h r * 5)-($ gas at 3 br*5) $))+2$
SCFA $(\mathrm{mmol} / 200 \mathrm{mg}$ DM $)=0.0222$ gas at $24 h r-0.00425$

Samples of the DPW and TDPW were analyzed for moisture, ash, ether extract, crude fiber and crude protein according to AOAC (1995).

The data were subjected to analysis statistical using SPSS statistics 22 (2013).

Table 1: Proximate analysis of date palm wastes (DPW) and treated date palm wastes (TDPW)

\begin{tabular}{lll} 
Components (\%) & DPW & TDPW \\
\hline Dry matter & 96.22 & 93.54 \\
\hline Ash & 33.07 & 15.79 \\
Crude protein & 8.04 & 12.02 \\
\hline Ether extract & 0.46 & 0.54 \\
Crude fiber & 35.52 & 41.28 \\
\hline Nitrogen free extract & 22.91 & 30.38 \\
\hline
\end{tabular}

\section{RESULTS AND DISCUSSION}

The proximate analysis of date palm wastes (DPW) and treated date palm wastes (TDPW) is presented in Table 1. The values of crude protein (CP), ether extract (EE), crude fiber $(\mathrm{CF})$ and nitrogen free extract (NFE) in TDPW were higher than that in DPW, might be due to the low 
content of ash in TDPW (15.79\%) compared to DPW (33.07\%). The crude protein of date palm leaves is usually low, about 4.83-7\% (El-Waziry et al., 2013; Arhab et al., 2006; Genin et al., 2004; Medjekal et al., 2011; E1-Hag and El-Khanjari, 1992) and the values of those authors are lower compared to the present values for DPW and TDPW (8.04-12.02\%). The increasing of CF and NFE in TDPW compared to DPW probably due to content of CF and NFE in mushroom residues contained TDPW, high cellulose and low lignin (Samsudin et al., 2013).

Table 2: cumulative of gas production $(\mathrm{ml})$ produce from date palm wastes (DPW) and treated date palm wastes (TDPW) during $72 \mathrm{~h}$ incubation time

\begin{tabular}{lllllllll|} 
& \multicolumn{7}{c|}{ Incubation time (h) } \\
& $\mathbf{3}$ & $\mathbf{6}$ & $\mathbf{9}$ & $\mathbf{1 2}$ & $\mathbf{2 4}$ & $\mathbf{4 8}$ & $\mathbf{7 2}$ \\
DPW & 2.44 & 8.67 & 12.00 & 14.22 & 19.78 & $23.33^{\mathrm{a}}$ & 23.44 \\
TDPW & 3.00 & 8.00 & 11.78 & 14.11 & 20.22 & $22.33^{\mathrm{b}}$ & 23.00 \\
sem $^{1}$ & 0.16 & 0.17 & 0.24 & 0.20 & 0.23 & 0.25 & 0.22 \\
p-value $^{1}$ & 0.77 & 0.93 & 0.50 & 0.79 & 0.35 & 0.04 & 0.33 \\
${ }^{1}$ standard error of means; ${ }^{a, b}$ mean values within a column with \\
unlike superscript letters were significantly different $(\mathrm{p}<0.05)$
\end{tabular}

Table 3: Parameters ${ }^{1}$ of gas production produced from date palm wastes (DPW) and treated date palm wastes (TDPW) during $72 \mathrm{~h}$ incubation

$\begin{array}{lll} & \mathbf{a + b}(\mathbf{m l}) & \mathbf{c}(\mathbf{m l} / \mathbf{h}) \\ \text { DPW } & 23.39 & 0.092 \\ \text { TDPW } & 22.94 & 0.094 \\ \text { sem }^{2} & 0.21 & 0.002 \\ \text { p-value } & 0.30 & 0.80\end{array}$

${ }^{1}$ cumulative gas production data were fitted to the model of Ørskov and McDonald (1979), Gas (Y) = a + b (1-exp $\left.{ }^{-c t}\right)$, where; $\mathrm{a}=$ the gas production from the immediately soluble fraction, $\mathrm{b}$ $=$ the gas production from the insoluble fraction, $\mathrm{a}+\mathrm{b}=$ potential degradability, $\mathrm{c}$ the gas production rate constant for the insoluble fraction (b), $\mathrm{t}=$ incubation time; ${ }^{2}$ standard error of means

Table 2 shows the cumulative of gas production produced from DPW and TDPW during $72 \mathrm{~h}$ incubation. The extent of gas production at $72 \mathrm{~h}$ was 23.44 and $23.00 \mathrm{ml}$ for DPW and TDPW, respectively. There was no significant $(p>0.05)$ difference between DPW and TDPW in gas production during $72 \mathrm{~h}$ incubation except at only $48 \mathrm{~h}$. The same trend was detected between DPW and TDPW in potential degradability $(\mathrm{a}+\mathrm{b})$ and the gas production rate (c) (Table 3). The values were 23.39 and $22.94 \mathrm{ml}$ for $\mathrm{a}+\mathrm{b}$ and 0.092 and 0.094 for $\mathrm{c}$ in DPW and TDPW, respectively. The values of gas production, $\mathrm{a}+\mathrm{b}$ and $\mathrm{c}$ in the present study are in agreement with the results of E1-Waziry et al. (2013). Although they evaluated dry date palm vs silage of date palm. The treatment of mushroom (Pleurotus florida) growing in of date palm wastes (called spent mushroom substrate) did not affect gas production, potential degradability and the rate of gas production in comparison with untreated date palm wastes. Gas production has been widely used to measure the nutritive value of feedstuff, crop by-product wastes and desert plants (El-Waziry et al., 2005; El-Waziry, 2007; El-Waziry et al., 2007; Razligi et al., 2011; Getachew et al., 1998).

Table 4: Predicted of metabolizable energy (ME), net energy (NE), organic matter digestibility (OMD) and microbial protein (MP) in vitro from date palm wastes (DPW) and treated date palm wastes (TDPW) during 24 $h$ incubation

\begin{tabular}{|c|c|c|c|c|}
\hline & $\begin{array}{l}\text { ME } \\
(\mathrm{MJ} / \mathrm{kg} \mathrm{DM})\end{array}$ & $\begin{array}{l}\mathrm{NE} \\
(\mathrm{MJ} / \mathrm{kg} \mathrm{DM})\end{array}$ & $\begin{array}{l}\text { OMD } \\
(\%)\end{array}$ & $\begin{array}{l}\text { MP } \\
(\mathrm{g} / \mathrm{kg} \text { OMD })^{1}\end{array}$ \\
\hline DPW & $5.35^{\mathrm{b}}$ & $3.06^{\mathrm{b}}$ & $38.23^{\mathrm{b}}$ & $46.11^{b}$ \\
\hline TDPW & $5.64^{\mathrm{a}}$ & $3.23^{\mathrm{a}}$ & $39.29^{a}$ & $47.39^{a}$ \\
\hline $\mathrm{sem}^{2}$ & 0.05 & 0.11 & 0.24 & 0.28 \\
\hline $\begin{array}{l}\mathrm{p} \text {-value } \\
{ }^{1} \mathrm{MP}(\mathrm{g} / \mathrm{kg} \\
\text { error of } \mathrm{m}\end{array}$ & 0.02 & $\begin{array}{l}0.02 \\
\text { rding to } \mathrm{C} z\end{array}$ & $\begin{array}{l}0.02 \\
\text { cawski }\end{array}$ & $\begin{array}{l}0.02 \\
1986) ;{ }^{2} \text { standard } \\
\text { mn with unlike } \\
<0.05)\end{array}$ \\
\hline
\end{tabular}

Predicted of metabolizable energy (ME), net energy (NE), organic matter digestibility (OMD) and microbial protein (MP) are given in Table 4. There were significant $(\mathrm{p}<0.05)$ differences between DPW and TDPW in ME, NE, OMD and MP, and The TDPW had the higher values compared to DPW. The increase of ME, NE, OMD and MP in TDPW vs DPW could be attributed to the increase of $\mathrm{CP}, \mathrm{EE}, \mathrm{CF}$ and NFE resulted to the treatment growing of mushroom in DPW. The trend of the present results is agreed with the results of Akinfemi and Ogunwole (2012) concerning to ME and OMD. There was no significant difference between linen straw and treated linen straw with white fungi in ME, NE, OMD and MP (Nasser et al., 2009).

Table 5: Gas production produced from soluble (GPSF) and insoluble (GPNSF) fractions of date palm wastes (DPW) and treated date palm wastes (TDPW) and short chain fatty acids (SCFA)

\begin{tabular}{llll} 
& $\begin{array}{l}\text { GPSF } \\
(\mathbf{m} 1 / 200 \mathbf{~ m g} \\
\mathbf{D M})\end{array}$ & $\begin{array}{l}\text { GPNSF } \\
(\mathbf{m l} / \mathbf{2 0 0} \mathbf{~ m g} \\
\mathbf{D M})\end{array}$ & $\begin{array}{l}\text { SCFA } \\
(\mathbf{m m o l} / \mathbf{2 0 0} \mathbf{~ m g} \\
\mathbf{D M})\end{array}$ \\
$\mathrm{DPW}$ & 9.10 & 90.40 & 0.43 \\
$\mathrm{TDPW}$ & 11.30 & 90.63 & 0.44 \\
$\mathrm{sem}^{1}$ & 0.87 & 0.59 & 0.01 \\
\hline $\mathrm{p}$-value & 0.18 & 0.85 & 0.35 \\
\hline
\end{tabular}

${ }^{1}$ standard error of means

Gas production produced from soluble (GPSF) and insoluble (GPNSF) fractions of date palm wastes (DPW) and treated date palm wastes (TDPW) and short chain fatty acids (SCFA) are shown in Table 5. There were no sig- 
nificant differences between DPW and TDPW in GPSF, GPNSF and SCFA, this is might be due to the gas production at $24 \mathrm{~h}$ of incubation. Because GPSF, GPNSF and SCFA were calculated using gas values produced in the media at $24 \mathrm{~h}$, and there was no significant difference between DPW and TDPW in gas production during the incubation time. The results of Akinfemi and Ogunwole (2012) are contrary with the present results of SCFA, due to the differences of the type of substrates, the type of fungi and the activity of microbes in the media.

There are a positive correlation between gas production and GPSF, GPNSF and SCFA in the current study. In general, gas production is mostly resulted of carbohydrates fermentation, while gas production from the fermentation of protein is quite small in comparison with carbohydrate fermentation, however gas produced from fat is negligible (Wolin, 1960). The in vitro gas production technique has been used to measure the energy value of feedstuffs (Getachew et al., 1998; El-Waziry et al., 2005, 2007; Aiple et al., 1996) particularly straws (Makkar et al., 1999; Nasser et al., 2009; Sallam et al., 2007) agro-industrial by products (Krishna and Gunther, 1987; Sallam et al., 2008) tropical feeds (Krishnamoorthy et al., 1995; Sallam, 2005, El-Waziry, 2007; El-Waziry et al., 2013) and grasses (A1Koaik et al., 2014). Determination of the digestibility of feeds in vivo technique is hard method, expensive, needful large amounts of feeds, and it is mainly unsuitable for single feedstuff so making it unacceptable for regular feed evaluation (Getachew et al., 2005). The gas production technique has been widely used as a simple method, suitable, fast, and allows a large number of samples to be evaluated. It could be concluded that fungal treatment of date palm wastes not only improved the CP contents but also improved ME, NE, OMD and MP. Mushroom treated date palm wastes "called spent mushroom substrate" have a good potential as feed resources for ruminant animals and could be used as useful source of fibre to supply the energy for ruminants.

\section{CONFLICT OF INTEREST}

The authors declare that they have no conflict of interest.

\section{AUTHORS' CONTRIBUTION}

All the authors contributed equally.

\section{ACKNOWLEDGEMENT}

The Authors extend their appreciation to the Deanship of Scientific Research at King Saud University for funding the work through the research group Project Number RGP-134.

\section{REFERENCES}

-Aiple KP, Steingass H, Drochner W (1996). Prediction of net energy content of raw material and compound feeds for ruminants by different laboratory methods. Arch Anim. Nutr. 49: 213-220. http://dx.doi. org/10.1080/17450399609381882

-Akinfemi A, Ogunwole OA (2012). Chemical composition and in vitro digestibility of rice straw treated with Pleurotus ostreatus, Pleurotus pulmonarius and Pleurotus tuber-regium. Slovak J. Anim. Sci. 45: 14-20.

-AlKoaikF,El-Waziry AM,KhalilAI,MetwallyH,A1-Mahasneh MA (2014). Evaluation of Conocarpus (Conocarpus erectus) Leaves and Bermuda grass (Cynodon dactylon L.) using chemical analysis and in vitro gas production technique. Bulg. J. Agric. Sci. 20: 824-829.

-AOAC (1995). Official methods of analysis. $16^{\text {th }}$ Ed. Association of Official Analytical Chemists, Washington, D.C.

-Arhab R, Macheboeuf D, Doreau M, Bousseboua H (2006). Nutritive value of date palm leaves and Aristida pungens estimated by chemical, in vitro and in situ methods. Trop. Subtrop. Agroecosyst. 6: 167-175.

-Bahman AM, Topps JH, Rook JA (1997). Use of date palm leaves in high concentrate diets for lactating Friesian and Holstein cows. J. Arid. Environ. 35: 141-146. http://dx.doi. org/10.1006/jare.1995.0145

-Blümmel M, Ørskov ER (1993). Comparison of gas production and nylon bag degradability of roughages in predicting feed intake in cattle. Anim. Feed Sci. Technol. 40: 109-119. http://dx.doi.org/10.1016/0377-8401(93)90150-I

- Czerkawaski JW (1986). An introduction to rumen studies. Pergamon Press. Oxford. New York.

-El-Hag MG, El-Khanjari HH (1992). Dates and sardines as potential animal feed resources. World Anim. Rev. 73(4): 15-23.

-El-Waziry AM, AlKoaik F, Khalil AI, Metwally H, AlMahasneh MA (2013). Estimation of degradability kinetics, energy and organic matter digestibility of date palm (Phoenix dactylifera L.) leaves silage by in vitro gas production technique. Asian. J. Anim. Vet. Adv. 8: 814-820. http://dx.doi.org/10.3923/ajava.2013.814.820

-El-Waziry AM, Nasser MEA, Sallam SMA, Abdalla AL, Bueno ICS (2007). Processing methods of soybean meal .2. Effect of autoclaving and quebracho tannins treated-soybean meal on gas production and rumen fermentation in vitro. J. Appl. Sci. Res. 1: 17-24.

-E1-Waziry AM, Nasser MEA, Sallam SMA (2005). Processing methods of soybean meal. 1- Effect of roasting and tannic acid treated-soybean meal on gas production and rumen fermentation in vitro. J. Appl. Sci. Res. 1: 313-320.

-El-Waziry AM (2007). Nutritive value assessment of ensiling or mixing acacia and atriplex using in vitro gas production technique. Res. J. Agric. Biol. Sci. 3: 605-614.

-Genin D, Kadri A, Khorchani T, Sakkal K, Belgacem F, Hamadi M (2004). Valorisation of date-palm by-products (DPBP) for livestock feeding in Southern Tunisia. I-Potentialities and traditional utilisation. In: Ben Salem, H., Nefzaoui A., Morand-Fehr, P. (eds). Nutrition and feeding strategies of sheep and goats under harsh climates (Stratégies de nutrition et d'alimentation des ovins et caprins en climats rigoureux), Zaragoza: CIHEAM-IAMZ, 227-232.

- Getachew G, Blümmel M, Makkar H, Becker K (1998). In vitro gas measuring techniques for assessment of nutritional 
quality of feeds: A review. Anim. Feed Sci. Technol. 72: 261281. http://dx.doi.org/10.1016/S0377-8401(97)00189-2

- Getachew G, DePeters EJ, Robinson PH, Fadel JG (2005). Use of an in vitro rumen gas production technique to evaluate microbial fermentation of ruminant feeds and its impact on fermentation products. Anim. Feed Sci. Technol. 124: 547559. http://dx.doi.org/10.1016/j.anifeedsci.2005.04.034

-Khalil AI, Alkoaik FN, Fulleros RB (2015). Preliminary Study for Cultivation of Oyster Mushroom (Pleurotus florida) on Agricultural Wastes in Saudi Arabia. Adv. Env. Biol. 9: 207215.

- Krishna G, Gunther KD (1987). The usability of Hohenheim gas test for evaluating in vitro organic natter digestibility and protein degradability at rumen level of some agro-industrial by-products. Land-wirtschaftliche forshung. 40: 281-286.

-Krishnamoorthy U, Soller H, Steingass H, Menke KH (1995). Energy and protein evaluation of tropical feedstuffs for whole tract and ruminal digestion by chemical analysis and rumen inoculum studies in vitro. Anim. Feed Sci. Technol. 52: 177188. http://dx.doi.org/10.1016/0377-8401(95)00734-5

- Makkar HPS, Aregheore EM, Becker K (1999). Effect of saponins and plant extracts containing saponins on the binding efficiency of ammonia during urea-ammoniation of wheat straw and fermentation kinetics of the treated straw. J. Agric. Sci. (Camb). 132: 313-321. http://dx.doi. org/10.1017/S0021859699006334

-Medjekal S, Arhab R, Bousseboua H (2011). Nutritive value assessment of some desert by-products by gas production and rumen fermentation in vitro. Livest. Res. Rural Dev. 23: 46.

- Menke KH, Raab L, Salewski A, Steingass H, Fritz D, Schneider W (1979). The estimation of the digestibility and metabolisable energy content of ruminant feeding stuffs from the gas production when they are incubated with rumen liquor. J. Agric. Sci. 93: 217-222. http://dx.doi. org/10.1017/S0021859600086305

- Menke KH, Steingass H (1988). Estimation of the energetic feed value obtained from chemical analyses and gas production using rumen fluid. Anim. Res. Develop. 28: 7-55.

- Nasser MEA, El-Waziry AM, Sallam, SMA (2009). In vitro gas production measurements and estimated energy value and microbial protein to investigate associative effects of untreated or biological treated linen straw and berseem hay. In: Nutrional and foaging ecology of sheep and goats; Edited by T.G. Papachristou, Z.M. Parissi, H. Ben Salem, P.
Advances in Animal and Veterinary Sciences Morand-Fehr. Pp. 261-266.

- Onodera R, Henderson C (1980). Growth factors of bacterial origin for the culture of rumen oligotrich protozoon, Entodinium caudatum. J. Appl. Bacteriol. 48: 125-134. http:// dx.doi.org/10.1111/j.1365-2672.1980.tb05214.x

- Orskov ER, McDonald I (1979). The estimation of protein degradability in the rumen from incubation measurements weighted according to rate of passage. J. Agric. Sci. 92: 499503. http://dx.doi.org/10.1017/S0021859600063048

-Pascual, JJ, Fernández C, Diaz JR, Garcés C, Rubert-Alemàn J (2000). Voluntary intake and in vivo digestibility of different date-palm fractions by Murciano-Granadiana (Capra hircus). J. Arid Environ. 45: 183-189. http://dx.doi.org/10.1006/ jare.1999.0622

-Razligi SN, Doust-Nobar RS, Sis NM, Fartash A, Salamatazar M, Aminipour H (2011). Estimation of net energy and degradability kinetics of treated whole safflower seed by in vitro gas production and nylon bag methods. Ann. Bio. Res. 2: 295-300.

-Sallam SMA, Nasser MEA, El-Waziry AM, Bueno ICS, Abdalla AL (2007). Use of an in vitro rumen gas production technique to evaluate some ruminant feedstuffs. J. Appl. Sci. Res. 3: 34-41.

-Sallam SMA, Bueno ICS, Godoy PB, Nozella EF, Vitti DMSS, Abdalla AL (2008). Nutritive value assessment of the artichoke (Cynara scolymus) by-product as an alternative feed resource for ruminants. Trop. Subtropi. Agroeco. 8: 181-189.

-Sallam SMA (2005). Nutritive value assessment of the alternative feed resources by gas production and rumen fermentation in vitro. J. Agri. Bio. Sci. 51: 200-209.

-Samsudin AA, Masori MF, Ibrahim A (2013). The Effects of Effective Microorganisms (EM) on the Nutritive Values of Fungal-Treated Rice Straw. Mal. J. Anim. Sci. 16: 97-105.

-SPSS (2013). SPSS for Windows Advanced Statistics Release 22: SPSS Inc. Chicago-Illinois.

- Van Gelder MH, Rodrigues MAM, De Boever JL, Den Hartigh, H, Rymer C, van Oostrum M, van Kaahthoven R, Cone JW (2005). Ranking of in vitro fermentability of 20 feedstuffs with an automated gas production technique: Results of a ring test. Anim. Feed Sci. Technol. 123-124: 243-253. http://dx.doi.org/10.1016/j.anifeedsci.2005.04.044

-Wolin MJ (1960). A theoretical rumen fermentation balance. J. Dairy Sci. 43: 1452-1459. http://dx.doi.org/10.3168/jds. S0022-0302(60)90348-9 